\title{
The Verbal Paradigm in the Narrative
}

The previous chapter dealt with the distribution and function of the indicative verbal forms in the dialogue. The present chapter is concerned with the verbal paradigm in the narrative and the way in which it shapes the overall structure of the text.

\subsection{Preliminaries}

As one of the most basic and pervasive phenomena of human life, narrative is hard to define in a compact precise fashion. Minimal definitions propose that a narrative is 'a perceived sequence of non-randomly connected events', ${ }^{1}$ and that narration means 'someone telling someone else that something happened'. In the vast literature on narrative structure, each of the elements referred to in these definitions, i.e., events, (ordered) sequence, teller and addressee, was thoroughly studied. Specifically, the relation between the 'real world' (or what we experience as such) and its configuration in narratives has been of special interest to modern theorists. Departing from a naive conception of the narrative as a recapitulation of 'past experience, ${ }^{3}$ Fleischman describes narrativization as the 'carving up of reality into constructs of experience, and the organization of these constructs into a verbal representation through which they acquire meaning. ${ }^{4}$ This understanding of the narrative as a cognitiveverbal construct suggests that narrative, by exploiting a well-defined linguistic schema, has both an objective property and a subjective one, which allows for a multiplicity of possibilities from which the narrator may choose to communicate his story.

Being a verbal construct, the narrative must be related in some way to the linguistic system as a whole. The question as to the specific locus of the narrative in language - either as a sub-system of the langue or as a special form of performance - was dealt with by some linguists and linguistically-minded

1 Toolan, Narrative, 6.

2 Herrnstein Smith, Narrative Versions, 228.

3 Labov and Waletzky, Narrative Analysis, 20.

4 Fleischman, Tense and Narrativity, 95.

(C) MICHAL MARMORSTEIN, 2016 | DOI: 10.1163/9789004310483_011

This is an open access chapter distributed under the terms of the Creative Commons

Attribution-Noncommercial-Non-Derivative 3.o Unported (CC-BY-NC-ND) License 
literary critics. Assuming that narrative indeed operates in a way different than the one found in ordinary discourse, then one should be able to identify some features that are not only characteristic but also distinctive of narrative discourse. For the most part, it is the use of the tense forms which is taken to provide the most obvious expression of the grammatical distinctiveness of narratives.

That narrating is not to be simply identified with the expression of past occurrences is implicit in the discussion of dedicated 'narrative forms' (such as wayyiqtol in Biblical Hebrew), ${ }^{5}$ or in the postulation of a basic 'narrative function' of a verbal form, such as foreground or background. ${ }^{6}$ However, the identification of the narrative as a system of its own implies that narrating is essentially distinct from other types of communication. Whether it exploits the same signifiers or introduces new ones, the narrative is a separate domain expressing a different set of meanings. This view of the narrative was proposed by linguists such as Benveniste and Weinrich, who set out to explain the underlying logic of the tense system in French (and to a lesser extent, in other European languages), and came to define two separate systems: one of narrative and one of non-narrative texts. For Benveniste, the hallmark of what he terms 'history' is the extensive use of the passé simple, which is by and large absent from the system of 'discourse. ${ }^{7}$ Weinrich goes even further to claim that the preterit does not depict past events, but it is rather an indicator of the erzählte Welt, as opposed to the beschprochene Welt, whose most basic indicator is the present. Both 'worlds' represent different 'speech-attitudes' assumed by the narrator and speaker. The internal opposition within the narrative system, especially between the preterit and the imperfect, is not temporal but comes into play in the dimension of grounding ('relief'). ${ }^{8}$ Hamburger holds a similar view regarding the 'a-temporality' of the preterit, which she considers as the index of narrative texts. For her, however, the subject matter is not the logic of the tense system but that of fiction against 'reality statements'. Fiction, which according to Hamburger is best represented in the third person epic, is by its very nature detached from the coordinates of the 'I-Origo' and hence devoid of

5 Dahl, Tense and Aspect, $113 \mathrm{ff}$.

6 According to Hopper, Aspect and Foregrounding, 217, the foreground-background distinction is 'universal of some kind', and aspectual distinctions, such as the ones found in Romance and Slavic languages, are 'derived from discourse' and not just 'ready-made devices "deployed" in discourse because they happen already to exist'.

7 Benveniste, Correlations of Tense.

8 Weinrich, Tempus, especially $38 \mathrm{ff}$. and $91 \mathrm{ff}$. 
a temporal value. In fiction, the preterit serves to tune the consciousness of the addressee to the situation of a story being told: 'for in the same moment with its appearance the preterit is no longer perceived as stating the past. The figures and events now portrayed "are" here and now'.

While espousing the view that 'languages do not treat narrating and asserting $[\ldots]$ in the same way', Fleischman questions the absolute division between narrative and non-narrative discourse as suggested above. ${ }^{10}$ For one thing, not all languages have a dedicated morphology for narratives; for another, some narratives - especially those which have originated in an oral form-may well disclose traces of ordinary discourse. In fact, the models mentioned above are too narrow and language-specific to serve as universal typologies of narrative discourse. Instead, Fleischman proposes a comprehensive model that is applicable to any type of discourse (see above 4.1). According to this model, each tense form embodies a cluster of concepts which belong to different levels of meaning, i.e., 'referential', 'textual', 'expressive' and 'metalinguistic'. At each level the form has a marked value, which is typical for a certain type of discourse. In narratives, the preterit is not simply a 'past form' or an 'a-temporal index of narrativity'. Rather, it is the unmarked form (as opposed to the marked present), which serves to depict past-perfective-sequential-foregroundedobjective-diegetic occurrences. ${ }^{11}$

Classical Arabic does not have verbal forms dedicated for narration. It does not have a clear signpost of narrativity such as wayyiqtol in Biblical Hebrew or the passé simple in French. Rather, the same forms which are used in narratives are also found in dialogues and generic utterances. Thus, in the search for grammatical indices of narrativity in Classical Arabic, one has to resort to more complex syntactic constructions and examine the way in which these contribute to what Labov and Waletzky have described as 'the overall structure of the narrative.'. ${ }^{12}$ Considering both their syntactic structure and textual function, we can identify three main types of narrative constructions or strategies: (a) the fa'ala-initiated chain, which mainly serves a referential or reportative

9 Hamburger, Logic, 81 .

$10 \quad$ Fleischman, Tense and Narrativity, 118.

11 Ibid., $53 \mathrm{ff}$.

12 Labov and Waletzky, Narrative Analysis. The authors mention two main functions of the narrative: 'referential' and 'evaluative'. The referential function is reflected in the temporal sequence of the narrative. However, a narrative that carries only a referential function 'lacks significance. The evaluative function is reflected in the narrator's attitude towards the content expressed, in his engagement in telling the story so as to convey a certain point. 
function; (b) kāna-clauses and syndetic circumstantial clauses, which constitute the orientation sections of the narrative; (c) mutually dependent constructions, which serve both a referential and an evaluative function. Of course, these constructions do not exhaust all types of clauses which can be found in narratives. However, they provide a defining key (at least from a grammatical point of view), for the presence of these types of constructions is sufficient to identify the text as narrative.

The studied corpus comprises narratives of various kinds: some are strictly fictional (e.g., the Kalila wa-Dimna tales) and some are transmitted in the form of historical records (e.g., Tabarì's Ta'rih $)$. However, as far as their syntactic and textual structure is concerned, both kinds of narratives present great similarity. Obviously, the external frame in which the narrative is embedded may inform us whether the story is real or fabricated, yet the narratives themselves do not disclose, at the formal level, any intrinsic signs for either fictionality or authenticity. ${ }^{13}$ Rather, the difference between both types of narratives resides in the proportions of their referential and evaluative components: the historical 'ahbār tend to be very informative and eventive, while the anecdotes collected in Kitāb al-'Ágannī or which are told by al-Ǧāhịiz are often less eventive and more expositive or impressionistic. This difference is sometimes reflected in the extensive use of expressive language in the latter texts, although expressivity is certainly not absent from the historic chronicles. ${ }^{14}$ As for the parameter which was earlier defined as 'deictic reference' (4.2), both fictional and (ostensibly) factual narratives can be recounted either by an internal and involved ('homodiegetic') first person narrator or by an external and detached ('heterodiegetic') third person narrator. ${ }^{15}$ The significant effect of the (literary) category of 'voice' is also manifested in the degree to which descriptive and expressive language is used in the narrative.

13 This is not to disavow the existence of a distinction between fictional and non-fictional narratives; my only claim is that 'hard-core' syntactic evidence cannot serve to substantiate this distinction, which apparently operates at a different level, lexical and/or rhetoric or pragmatic. For a discussion of the question of fictionality in Classical Arabic prose, specifically in learned literature, see Leder, Conventions.

14 For a short description of the literary structure of the 'ahbār and the narrative techniques through which they are shaped, see Leder and Kilpatrik, Classical Arabic Prose, $10 \mathrm{ff}$.

15 Genette, Narrative Discourse, 228 and 243 ff., distinguishes between different forms of involvement of the narrator in the narrative: the narrator may be 'intradiegetic' or 'extradiegetic', depending on whether his voice is internal or external, 'homodiegetic' or 'heterodiegetic', depending on whether he participates in the plot. 
The following discussion will focus on the three main types of narrative constructions mentioned above. For that purpose, I will not distinguish between fictional and factual narratives; the distinction between first person and third person narratives will be recalled whenever a syntactic particularity can be attributed to it.

\subsection{The Main-line: fa' ala-initiated Chains}

\subsubsection{The fa'ala coNN-fa'ala Pattern}

It was mentioned above that narratives, according to the simplest definitions, serve to convey an ordered sequence of events. Indeed, sequentiality is often considered to be the most basic and indispensable characteristic of narratives. The linguistic exponent of narrative sequence is the chain structure. In Classical Arabic, the chain is most commonly realized in a symmetrical configuration of connected fa'ala forms, formulized as fa'ala conN-facala. ${ }^{16}$ The connective particles are: $w a$ - 'and', $f a$ - 'and then', tumma 'thereafter' and $h a t t \bar{a}$ 'until'. These connectives are distinct from each other in their degree of specificity: $w a$ - is the least marked connective, $f a$ - conveys the general meaning of tartīb 'order', tumma indicates the passage of a certain interval of time, hatta the arrival at the destination or final stage of a series of events (see above 6.1.3). Each fa'ala form stands for a narrative event. Eventhood is often associated with dynamicity and affectedness, with 'happenings' or changes of situations. However, this is not necessarily the case: the event indicated by facala may well be of a static or a-telic nature. Regardless of the inherent structure of the verbal lexeme, the event indicated by fa'ala is interpreted as discrete, particular, and sequential, as illustrated in the following excerpt:

(10.1) fa-rağa'ù 'alā hāmiyati-him ḥattā qadimū l-madinata fa-nazalū-hāa

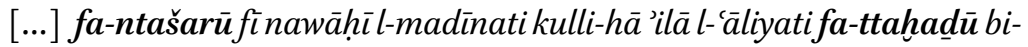
hà l-āạtāma wa-l'amwāla wa-l-mazāri'a wa-labițū bi-l-madinati zamā-

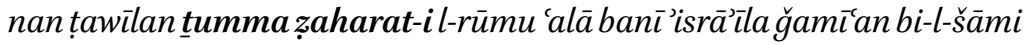
fa-wațiū-hum wa-qatalū-hum

16 In this formulation, conN stands for 'connective'. Since the initial facala can also be preceded by a connective, a more precise way of representation would be (CONN-) fa'ala conN-fa'ala. However, to avoid a cumbersome formula, it will be implicitly assumed that each initial fa'ala also represents (CONN-) fa'ala. By 'symmetrical configuration' I mean that the adjacent clauses have the same syntactic status, and not that their coordination is symmetrical, i.e. reversible. 
Then they went back to their garrison until [finally] they arrived at Medina and stopped over there [...] then they scattered all through Medina as far as al-'̄liya (the upper city), and they got for themselves in it fortified houses, orchards and fields, and they dwelt in Medina for a long time. Then, the Romans overcame all of the Israelites in al-Šām, trampled them down, and killed them. (Riwāyāt 2, 8)

This short narrative demonstrates how the connectives are combined with various types of events recounted in the facala form. The events range from purely static and intransitive situations, such as labit $\bar{u}$ 'they dwelt', to highly dynamic and transitive situations, such as qatalu 'they killed'. That all the events are interpreted as bounded and discrete is not due to the perfective meaning of the unmarked narrative form (see above 10.1, Fleischman's characterization of the preterit): we recall that outside the chain, when facala occurs with stative lexemes it indicates unbounded persistence (see above 9.2.1). Rather, the perfective meaning is imposed by the sequential structure of the narrative chain. For in reality, the events recounted in the quoted passage did not necessarily follow in order, or were even experienced as 'complete events' at all. For instance, the overcoming of the Israelites was obviously not accomplished before they were all trampled down and killed. The verb zaharat serves, in fact, as an abstract for the following wați $\bar{u}$-hum and qatalu-hum, the same way as the verb labitūu serves as a coda for the preceding intašarū and ittahadū.

The quoted passage reports on the settling of the Jews in Yatrib, the historical Medina. The story is set in an historical framework; however, it abounds with fictional and even mythical elements. It is recounted by a third person narrator, who assumes a detached, absent or omniscient position. The point of reference of the narrative is therefore internal. The question of whether the reported events took place in a real time or not is quite irrelevant. As far as its temporality is concerned, this narrative is ageless: it is self-contained and discloses no relation to the situation of narration. This is obviously not the case in the following passage, where the story is related by an involved first person narrator:

(10.2) țumma ndafa'tu fa-ġannaytu l-șawta fa-wațabat-i l-ğāàiyatu fa-qālat limawlā-hā hādā wallāhi 'abū 'uțmāna bnu misğahin fa-qultu 'ì wallāhi 'anā huwa wallāhi lā 'uqìmu inda-ka

Then I burst and sang the song and the maid jumped and said to her master: 'By God, this is 'Utmān b. Misğah.' And I said: 'Indeed, by God, this is me; by God I will not stay with you.' (Riwāyāt 1, 25) 
The first person sets an external point of reference to the narrative. In this case, fa'ala encodes the detachment of the narrative sphere from the situation of narration. Between the two ends of an impersonal third person narrator, as illustrated in [10.1], and a personal first person narrator, as illustrated in [10.2], there are other types of narrative transmission or 'mediacy', to use Stanzel's terms. ${ }^{17}$ It is evident, then, that we cannot say for all narratives that a temporal sense of fa'ala is either absent or given; rather, the temporal interpretation of facala becomes relevant whenever it operates in a relative deictic system, typically constituted by the first person narrator, whether the latter is a real person or is just a creation of the author's imagination.

\subsubsection{The fa'ala yaf'alu/fā'ilan Pattern}

The designation of fa'ala as the narrative form or as eventive should be understood, in line with the above discussion, as referring to the dominant role played by facala in the construction of the narrative chain. This does not mean that fa'ala in all cases depicts the typical (dynamic and transitive) event, or that other verbal forms besides fáala cannot convey narrative events. In fact, we observe two other patterns of narrative chaining which, contrary to the fa'ala conN-facala pattern, are asymmetrical configurations. The first is a chain involving a verbal complex, the second features the pattern fa'ala fa-yaf'alu, which will be dealt with in the following section.

It is often the case that in the historiographical literature several versions of the same story are adduced. This practice is quite useful (also) for our matter, as it brings to the surface the distinction between various manifestations of what literary critics call 'point of view', 'perspective' or 'focalization', to wit, the position from which the events are perceived (rather than told). ${ }^{18}$ As mentioned, in Classical Arabic the narrative most commonly unfolds in the fa'ala CONNfa'ala pattern, signaling an 'event-by-event' pace. However, the same series of events can also be recounted in the form of a verbal complex of the pattern fa'ala yaf'alu or fa'ala fä́ilan. In using the verbal complex, two events are compressed into a single common occasion (see above chapter 8 ). The following examples illustrate these two patterns of narrative transmission; the verbal complex in [10.4] comprises the predicative participle:

17 The term 'mediacy' refers to the indispensable presence of some sort of 'mediator' whenever a story is being told. According to Stanzel, Theory of Narrative, 4, mediacy is 'the generic characteristic which distinguishes narration from other forms of literary art'.

18 The recognition that 'perspective' or 'focalization' ('who sees') and 'voice' ('who speaks') are two distinct categories in narrative structure was given its clearest expression in Genette's Narrative Discourse. 


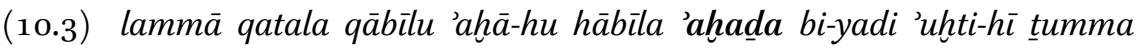
habața bi-hā min ğabali būda fi l-ḥadìdi

After Cain killed his brother Abel he took his sister by the hand and

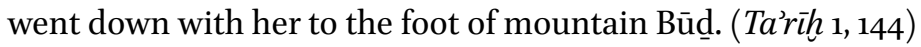

(10.4) fa-ḥasada-hū qābïlu fa-qatala-hū 'inda 'aqabati hirā̄a tumma nazala

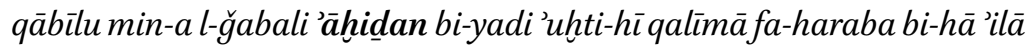
'adana min 'ardi l-yamani

Cain thus envied [Abel] and killed him on the mountain slope of Hirää. Then Cain descended from the mountain, holding his sister Qalīmā by the hand, then he fled with her to 'Adan in the land of Yemen. (Ta'rīh 1 , 144)

The two versions refer to the same tradition: Adam wanted to marry Cain's twin sister to Abel but Cain refused. The two then offered sacrifices of which only Abel's was accepted. Cain thus became envy of Abel, killed him on the top of a mountain and fled with his sister. Though recalling the same tradition, the narrators of [10.3] and [10.4] mold the events into two different patterns: the facala CONN-fa'ala chain in the first, the verbal complex in the latter. Though the difference between both strategies is subtle, a couple of distinctions can still be observed. Firstly, the fa'ala conN-fa'ala chain imposes a certain chronology on the events: Cain first took his sister by the hand and then descended from the mountain. The verbal complex, on the other hand, leaves the exact chronology unspecified and depicts a scene in which the two events, now related in inverse order (first 'descending' then 'taking'), converge. Secondly, the version in [10.3] displays a sheer reportative style. The events, which are all externally observable ('kill', 'take', 'go down'), are condensed into a temporal lammā-clause and a chain of fa'ala forms. The story is thus structured as a flat sequence, in which no event stands out as more important or central than the other. In contrast, the version in [10.4] displays a descriptive and elaborate style. The narrator sets out from describing Cain's emotional state (hasada-hū), which led him to kill Abel. He then employs the verbal complex to linger on the picture of Cain descending from the mountain while holding Qalīmā's hand, after he had 'won' her. By using the verbal complex, the narrator shifts from external to internal focalization, thereby marking a certain scene as a salient moment in the narrative. The next example illustrates the use of a verbal complex comprising the predicative yaf'alu:

(10.5) lammā 'ağma'a 'abū salamata l-hurūğa 'ilà l-madīnati rahala lì ba'îrahū tumma hamala-nı̄ 'alay-hi wa-ḥamala ma'̄ bn-ī salamata bna 'abì 
salamata fi ḥağr-ì țumma harağa bì yaqūdu baìra-hū [...] fa-nazacū hițāma l-baîri min yadi-hì fa-'ahadū-nīmin-hu

When 'Abū Salama had decided to depart to Medina, he saddled his camel for me, then he mounted me on the camel together with my son Salama b. 'Abī Salama [who was] in my arms, then he went out with me leading his camel [...] so they snatched the camel's halter from his hand and took me from him. (Sira 1, 314-315)

The narrator tells the story about her family's migration to Medina, specifying that her husband was leading (yaqüdu) the camel, upon which she and her son were seated, when they first departed. This fact turns later to be significant, when we are told that the camel's halter had been snatched by some tribesmen, thus separating the wife and son from the husband. The narrator uses the verbal complex to portray the scene of departure in details, thereby underscoring the relevance of its specific manner of unfolding to the succeeding narrative. This strategy is not restricted to either the third person or the first person narrator: both employ the verbal complex as a special channel of story transmission, allowing them to inspect more closely the narrated scene.

\subsubsection{The fa'ala fa-yaf'alu Pattern}

So far, two forms of narrative chaining have been discussed: the unmarked fa'ala CONN-fa'ala pattern, and the verbal complex pattern, marking an internally focalized chain of events. A third pattern, far less attested, consists of the sequence fa'ala fa-yaf'alu. In contrast to the fa'ala conN-fa'ala pattern, fa'ala fa-yaf'alu does not exhibit a symmetrical configuration, where each link has the same syntactic status. Unlike the asyndetic yaf'alu in the verbal complex, $f a-$ yaf'alu is not embedded but connected to the previous fa'ala. We may say, thus, that fa-yaf'alu holds an intermediate position between the two other patterns: $f a-y a f^{\prime} a l u$ is dependent on the previous fa'ala, which initiates the chain, yet it is not paradigmatic with the predicative participle and therefore not embedded. Also, as far as its function is concerned, we may define fa-yaf'alu with respect to its two other competitors, fa-fa'ala and $\varnothing$-yaf'alu. Comparing the following set of examples:

(10.6) ̦umma nșarafū fa-wağadū qurayšan bi-bațni rābig̈in

Then they turned and found Qurayš in Bațn Rābig̀. (Mag் $\bar{a} z \bar{l}, 205)$

(10.7) fa-'aqbalū naḥwa-humā yastami'ūna

And they came toward them to listen closely [to their talk]. (Riwāyāt 1, 253) 
(10.8) fa-ndafa'ū tilqā̉al-zuraybifa-yağidūna 'alà tilka l-qalībillatī qāla rasūlu llāhi rawāya à qurayšin fì-hā suqqāu-hum

They proceeded towards al-Zurayb and found at that well, which the Messenger of God mentioned, the watering camels of Qurayš [and] in it their water carriers. (Mag் $\bar{a} z \bar{\imath}, 51)$

We observe that the pattern fa'ala fa-yaf'alu indicates something different than mere sequence. While nșarafü fa-wağadū in [10.6] indicates an 'event-by-event' progression and fa-'aqbalū [...] yastami'üna in [10.7] indicates a compressed dynamic progression, fa-ndafa $\bar{u}$ [...] fa-yağidūna in [10.8] indicates a logical sequel, a relation of consequence, result, or reaction of one event to a previous event. Table 10.1 below summarizes the syntactic and semantic distinctions between these three patterns of narration:

TABLE 10.1 Patterns of main-line sequence in the narrative

\begin{tabular}{|c|c|c|}
\hline Pattern & Syntactic status & Semantic relation \\
\hline fáala fa-fa'ala & independent & chronological sequence \\
\hline $\begin{array}{l}\text { fa'ala fa-yaf'alu } \\
\text { fa'ala yaf'alu }\end{array}$ & $\begin{array}{l}\text { dependent, not embedded } \\
\text { embedding }\end{array}$ & $\begin{array}{l}\text { logical sequel } \\
\text { event integration }\end{array}$ \\
\hline
\end{tabular}

Although of marginal use, the pattern fa'ala fa-yaf'alu did not escape the attention of some Arabists, notably Nöldeke and Nebes. Nöldeke suggested that an imperfect following a narrative perfect serves to indicate a 'concluding action.' ${ }^{19}$ In a footnote he adds that the construction in Arabic is exactly like the waw conversivum in Biblical Hebrew, the only difference is that in Arabic this construction is rare whereas in Hebrew it is the rule.

The resemblance that Nöldeke pointed to between the Arabic and the Hebrew forms appears to me as untenable. The form wayyiqtol in Biblical Hebrew is 'the most usual method in which a series of events is narrated. ${ }^{20}$ As demonstrated by Niccacci, wayyiqtol can be used in both initial and medial positions, and it is not marked particularly for the meanings of consequence or result. ${ }^{21}$ Moreover, the formal resemblance between fa-yaf'alu and wayyiqtol

\footnotetext{
19 Nöldeke, Zur Grammatik, 68.

20 Driver, Treatise, 73.

21 Niccacci, Syntax of the Verb.
} 
(which in itself is not perfect) is no evidence for their functional identity. In fact, the verbal systems of Classical Arabic and Biblical Hebrew are fairly different from each other. A significant point of divergence is reflected indeed in the use of fa'ala versus that of wayyiqtol as an index of the narrative chain, and the use of yaf'alu (in various types of clauses) versus that of qațal to express background information.

Another way to understand the sequence fa'ala fa-yaf'alu was proposed by Nebes. ${ }^{22}$ Nebes endeavors to explain the temporal value of yaf'alu which, in spite of being what he sees as independent form, is interpreted as past rather than present tense. According to Nebes, yaf'alu in these cases obtains the 'fictive' present time of the subject of the narrative, rather than referring to the real time of the narrator or the speaker. This change of perspective, from the narrator to the dramatis personae, is aimed, according to Nebes, to enliven the narrative.

We have seen earlier (10.2.2) that an alternation of chaining patterns may signal a change of perspective in the narrative. The normal fa'ala conn-fa'ala pattern marks a quick pace of narration, while transition to the fa'ala yaf'alu/ făcilan complex reduces the speed to allow lingering on some particularities of the narrated event. When yaf'alu functions as the predicative form in the complex, the time reference of the event is not changed but only its aspectual contour, affecting in turn a change of perspective, from a distanced and external one to a closer and internal one.

The pattern fa'ala fa-yaf'alu, as opposed to fa'ala yaf'alu, does not feature an embedded predicative form but a connected sequential form. Nevertheless, fa-yaf'alu cannot be regarded as syntactically independent, as it can only occur in a subsequent position in the chain, dependent on the initial fa'ala which determines the time reference of the entire chain. Furthermore, the rare, isolated, and contextually restricted environments in which fa-yaf'alu is found make it hard to consider it as an instance of historic present, which is generally unknown in Classical Arabic prose. Rather than marking a temporal/perceptual shift, fa-yaf'alu is employed to stress the (con)sequential relation between two succeeding events. In the reminder of this section, I shall closely examine a variety of examples in which fa'ala fa-yaf'alu is used, in the attempt to better explain both the semantic and textual functions of this pattern of narrative chaining.

The case where a sequential $f a-y a f^{\prime} a l u$, specifically the verb fa-yağidu, follows a motion verb is relatively common. Example [10.9] is another such case. 
This example is extracted from a story about the Prophet asking his 'așhāa, who stayed in Abyssinia, to join him in Medina. After they had come, they found out that - against their expectation — the Prophet was not in Medina, as he had already left to Haybar. The verb 'to find' appears twice: first fa-yağidūna then $f a$-wağadū. The first 'finding' of the 'așhāb is marked as the result of their purposive coming to Medina to meet the Prophet. The second 'finding' is not as sensational, grammatically speaking; it is a further step in the chain of events:

(10.9) hạttā qadimū l-madīnata fa-yağidūna rasūla llāhibi-haybarafa-šahașū 'ilay-hifa-wağadü-hu qad fataha haybara

Until they came to Medina and found out [that] the Messenger of God was in Haybar, and they turned towards him and found out [that] he had already conquered Haybar. (Ibn Sa'd 1/1, 139; Nebes, Kāna Yaf'alu, 196)

In a second group of cases, the sequential fa-yaf'alu follows an action verb. The subject is switched from fa'ala to yaf'alu, so that the sequence expresses an ensuing reaction of one party to the action of another. The pattern facala $f a-y a f^{\prime} a l u$ marks the situation as a salient and dramatic moment in the story. Notice that after the junction of fa'ala fa-yaf'alu the narrative continues in the normal sequence of fácala forms:

(10.10) fa-'ahada l-liwāà bi-l-yusrā fa-'ahmilu 'alāyadi-hìl-yusrā fa-ḍarabtu-hā fa-qațatu-hā

He took the flag in his left hand, so I attacked his left hand and struck it and cut it. (Maḡāzi, 227)

(10.11) fa-qultu sta'sirā fa-'abayā fa-'armì 'ahada-humā bi-sahmin fa-'aqtuluhü wa-sta'sara l-āharu

I said: 'Surrender [you two]!' And they refused [to surrender], so I threw an arrow at one of them and killed him and [then] the other one surrendered. (Sïra 2, 994)

In a third group of cases, the sequential $f a-y a f^{\prime} a l u$ occurs after direct speech: $f a-y a f^{\prime} a l u$ reacts not to a previous action in the narrative, but to the content of the speech, or a certain implication thereof. In [10.12] the look at the gazelle is interpreted as a call for hunting; in [10.13] the speakers intend to make the loud singer silent; and in [10.14] the donkey tries to comply with Noah's order: 
(10.12) lammā kunnā bi-turbāna qāla lì rasūlu llāhi yā sa'du nz̧ur 'ilā l-zabyi qāla fa-'ufawwiqu la-hū bi-sahmin

When we were in Turbān the Messenger of God said to me: 'O Sa'd, look at the gazelle!' (he said) So I aimed an arrow [to throw] at it. (Mag்azi, 26)

(10.13) fa-sami'a-hū l-rukbānu fa-ğa'alū yașịhūna bi-hì yā șāhhiba l-șawti 'a-mā tattaqī llāha qad habasta l-nāsa 'an manāsiki-him fa-yaskutu qalīlan hattā 'idā madaw rafa'a șawta-hū

The riders heard him and started to shout at him: 'O you of [loud] voice (lit. 'owner of voice'), do you not fear God? You have already withheld the people from their rituals of pilgrimage.' So he became silent for a short while until they went away [then] he raised his voice. (Riwāya àt 1 , $51)$

(10.14) fa-lammà ’adhala l-himāra wa-dahala șadru-hū táallaqa 'iblìsu la'anahū llāhu bi-danabi-hì fa-lam tastaqilla riğlà-hu fa-ǧa'ala nūḥu yaqūlu wayhaka dhul fa-yanhaḍ fa-là yastațīu

When he brought in the donkey and its front part was inside, 'Iblīsmay God curse him!- - clung himself to its tail and so its legs could not board [the ark]; Noah started to say: 'Woe to you! Step in!' So [the donkey] rose but could not [go in]. (Ta'rīh 1, 190)

In the last two examples the introduction of speech was made by a verbal complex: ğa'alū yașihhūna, ğa'ala yaqūlu. It is often the case that ğa'ala yaf'alu initiates a chain followed by the sequential fa-yaf'alu. In these cases, too, the meaning of ensuing reaction or result can be discerned: in [10.15] Noah builds the ark on land and this action naturally brings about the reaction of astonishment, and later scorn, of his people; in [10.16] young Abraham asks his father about creatures in the world and his father thus tells him about each creature:

(10.15) țumma ğa'ala ya'malu safinatan fa-yamurrüna fa-yas'alūna-hü fa-yaqūlu' 23 'a'malu-hā safinatan fa-yasharūna min-hu fa-yaqūlūna ta'malu safinatan fì l-barri fa-kayfa tağrì fa-yaqūlu sawfa talamūna

23 Given its specific quotative function and its frequent interchanging with $(f a-) q \bar{a} l a$ (see also below 11.3), the form fa-yaqülu is not regarded as an instance of the $f a-y a f^{\prime} a l u$ chaining pattern. 
Then he started to build an ark and they passed by and asked [what was he doing] so he said: 'I am building an ark from it.' They made fun of him and said: 'You are building an ark on land, how could it float?! So he said: 'You will know.' (Ta'rīh 1, 186)

(10.16) fa-ğa'ala yas'alu 'abā-hu mā hādā fa-yuhbiru-hū 'an-i l-ba'îri 'anna-hū ba'ìrun wa-'an-i l-baqarati 'anna-hā baqaratun wa-'an-i l-farasi 'annahū farasun wa-'an-i l-šāti 'anna-hā šātun

And he started to ask his father what is this, so he told him about the camel that it is camel, and about the cow that it is cow, and about the horse that it is horse, and about the sheep that it is sheep. (Ta'rin 1,258 )

The chains in [10.15] and [10.16] may appear as an extension of the verbal complex, viz.: ğa'ala yas'alu ... fa-yuhbiru-hū. The complex ğa'ala yas'alu indeed indicates a modified event 'he started to inquire'. However, this modification does not apply to yuhbiru which has a different subject. Rather than an inchoative meaning, fa-yuhbiru-hu has an iterative sense which is not affected by ğa'ala, meaning 'to start', but brought about by the plurality of the complements of the verb. That the sequential $f a-y a f^{\prime} a l u$ is not just a second predicate added to the chain can be demonstrated by the next pair of examples:

(10.17) fa-ġannaytu-hū 'iyyā-hu wa-mā zāla yaqtarihu 'alay-ya kulla șawtin ġunniya bi-hī fì šíri-hī fa-'ugianni-hi wa-yašrabu wa-yabkī hattā șāratil-atamatu

I sang it to him and he incessantly demanded of me [to sing] every song that was sung of his [repertoire of] poems, so I sang to him and he was drinking and crying until night has come. (Riwāyāt 1, 4)

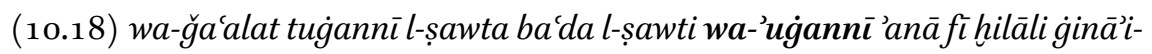
$h \bar{a}$

She started to sing one song after the other and I [too] was singing during her singing. (Riwāyāt 1, 249)

In [10.17] the chain is initiated by the modifying verb $m \bar{a} z \bar{a} l a$ 'to continue'; $f a$ 'uganni-hi reacts to the previous action and complies with the demand to sing. In this case, too, the iterative meaning rises from the plurality of the (elliptic) object, i.e., the entire repertoire of songs. $f a-{ }^{-} u \dot{g} a n n \bar{i}-h i$ is continued by $w a-$ yašrabu wa-yabkī which clearly do not indicate this kind of logical relation. In contrast to that, wa-'ugannī in [10.18] is not ensuing but rather (as indicated by the adverbial fi hiläli) coinciding with the previous event. 
It is not surprising that $f a-$, rather than wa- or tumma, is the connective used to mark this logical relation of result and consequence. We recall that the basic function of $f a$-is to indicate an ordered sequence. However, the precise semantological nature of this sequence is not indicated by $f a$-but left to the specific structure and context. For this reason, $f a$ - may be found in a variety of macro-syntactic structures where the meaning of sequel holds, e.g.: the narrative chain, the ğawāb 'apodosis' of conditional constructions (and other bipartite constructions, such as those discussed above in 8.4), and explicative clauses introduced by fa-inna. It is interesting to note in this regard the structural similarity between the sequential $f a-y a f^{\prime} a l u$ and $f a-y a f^{\prime} a l a$. The indicative form yaf'alu follows the indicative form fa'ala to express the meanings of result and consequence, while the subjunctive yaf'ala follows a modal (or a non-assertive) clause-an imperative, a prohibitive, an interrogative or an optative clause - to express a similar meaning. The occurrence of both yaf'alu and yaf'ala is predetermined by the preceding clause: yaf'alu is never initial in the narrative chain and it is dependent upon fa'ala; yaf'ala is nowhere initial and independent but conditioned by a set of operators and forms (see above $5 \cdot 3) \cdot{ }^{24}$ Table 10.2 summarizes the comparison between both forms:

TABLE 10.2 fa-yaf'alu $v s$. fa-yaf'ala

\begin{tabular}{|c|c|c|c|}
\hline Indicative & fáala & $f a-y a f^{\prime} a l u$ & result \\
\hline Modal & if'al, lāyaf'al, hal ..., layta ..., lā ... & $f a-y a f^{\prime} a l a$ & effect \\
\hline
\end{tabular}

\subsection{The Background}

A narrative is rather dull (and perhaps not a narrative at all) if it consists of a plotline only. The part of the narrative which is not foregrounded is far more complex and diversified, both formally and functionally. Shisha-Halevy, in his discussion of the narrative texteme, calls that part the 'comment mode' (as opposed to the 'evolution mode'), and defines it as 'extrinsic and typically anaphoric to the plot, but often internal to the narrator's perspective'. ${ }^{25}$ The

\footnotetext{
24 Cf. Sadan, Subjunctive Mood. The existence of free yaf'ala forms was acknowledged by some grammarians, however these were always regarded as exceptional (282).

25 Shisha-Halevy, Topics, 34.
} 
comment mode is the domain where the events are explained, resumed and given reasons by the narrator, who always keeps an open (even if implicit) channel for his accompanying voice. The background of a narrative is accordingly 'but one component of the comment mode' and ought to be regarded as 'roughly synonymous to "setting information".,26

In this section I will not deal with the entire complexity of the comment mode, but only make some observations regarding the background or orientation component. Labov and Waltezky define orientation as that section of the narrative which serves to 'orient the listener in respect to person, place, time and behavioral situation. ${ }^{27}$ The orientation typically precedes the plot, although it can be found in other places as well. It may be realized through a great number of syntactic structures, and even be encapsulated in some lexical items. ${ }^{28}$ The orientation is not necessarily presented in an objective or impersonal manner, but may well convey (in a more or less explicit form) the evaluation of the narrator.

In the following, I will discuss two types of clauses which form the greater part of background units in Classical Arabic narratives, i.e., kāna-clauses and syndetic circumstantial clauses. Both types of clauses will be described considering two distinctions: a syntactic one and a functional one. Firstly, a distinction between independent ('free') and dependent background clauses will be drawn. Secondly, I will distinguish between background clauses which are eventive and those which are non-eventive or descriptive.

\subsubsection{Free and Dependent Clauses}

As was earlier discussed (see above 6.1.2), the dependency status of a clause in Classical Arabic is determined by a number of features, such as the position of the clause in the sequence, the (a)symmetrical configuration it assumes relative to the adjacent clause, and its substitution class. Clauses initiated by kāna, as opposed to syndetic circumstantial clauses, can occur as main clauses. Being syntactically independent, they may assume any position in the sequence, initial as well as subsequent. In the narrative, $k \overline{a n} a$-clauses are the typical example of what Labov and Waletzky define as 'free' clauses, i.e., clauses which are not constrained by the temporal sequence of the narrative and thus

\footnotetext{
26 Ibid.

27 Labov and Waletzky, Narrative Analysis, 32.

28 The case of proper names is of particular relevance for that matter. Proper names can connote the full setting of a story in terms of the place, time, culture, persona and even the expected course of events.
} 
can 'range freely through the narrative sequence'. ${ }^{29}$ This should not be taken to mean that kanna-clauses occur randomly in the text: though they do not form part of the chronological sequence, kāna-clauses (like all other clauses in the narrative) are subject to the logical order of narration itself, that is, to the author's decisions as to which information is best suited to which part in order to convey the desired effect. Thus, the text may feature the same information in the beginning, where the orientation is commonly found, or as a comment inserted in the body of the text:

(10.19) kāna ma'badun qad 'allama l-g̈ināa ğāriyatan min ğawārī l-hiğāzi tud'ā zabyata wa-'uniya bi-tahrĭği-hā fa-štarā-hā rağulun min 'ahli l-irāqi

Ma'bad had taught the singing to a maid from Hiǧāz named Ẓabya; he was invested in her becoming an accomplished [singer]. Then, a man from the people of Iraq bought her. (Riwāyāt 1, 9)

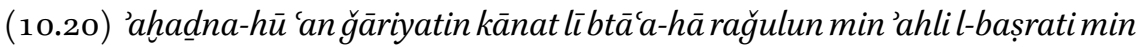
makkata wa-kānat qad 'ahadadat 'an 'abì 'abbādin ma'badin wa-'uniya bitahrï̆gi-hā

They learned it (i.e. the song) from a maid I had, whom a man from Basra had bought from Mecca, and she had learned it from 'Abū 'Abbād Mabad; he was invested in her becoming an accomplished [singer]. (Riwāyāt 1, 11)

In [10.19], the details about Macbad and the maid are presented for an introductory purpose: they anticipate the story and bear on the entire text which will follow. By contrast, in [10.20] the same details have an explicative function: they aim to fill a local gap in the state of knowledge of the persons involved in the story. In the first case the kanna-clause serves as general background, in the latter case it serves to answer a specific question.

While kāna-clauses can occur both in an initial and a subsequent position in the sequence and thus serve both an introductory and an elaborative function, syndetic circumstantial clauses are dependent upon the preceding clause and can only serve the latter function. The circumstantial clause, like a subsequent kāna-clause, has a local scope of application, i.e., it elaborates on a certain topic - a situation or an entity - which were previously mentioned in the text. Nevertheless, the circumstantial may exceed the referrential world of the narrative, when conveying an authorial comment or an encyclopedic piece of information. Consider, for instance, the example below: 
(10.21) la-qad rảaytu-nā hìna balaginā l-țaniyyata l-bayḍ̄àa wa-l-țaniyyatu lbayḍāu llatī tuhbițu-ka 'alā fahhin wa-'anta muqbilun min-a l-madīnati I saw us as we reached the white pass, and the white pass is that which brings you down to Fahh as you come from Medina. (Maj $\bar{a} z \bar{z}, 35)$

In [10.21], the point of reference of the circumstantial clause - which elaborates on the geographical location of a place mentioned before-resides outside the narrative sphere: it is located in the here-and-now of the situation of narration itself. Such cases bring to the fore the existence of the 'implied author' of which we are usually unconscious. ${ }^{30}$

Circumstantial clauses which take the form of an 'inna-clause present us with a different case. As noted earlier (see above 8.3), the wa-inna la-pattern has an emphasizing function: it stresses the validity or veracity of the content of the clause in relation to some other implicit or explicit (counter-)assumption. When the wa-inna la- pattern is used it is not the external voice of the author that is expressed; rather, it is an expression of the narrtor's internal stance, whether it be the first person or third person narrator, as illustrated below:

(10.22) ḥattā ’aqbala rağulun min-a l-ğinni min 'asfali makkata yataġannā bi'abyātin min širin gìnāa l-arabi wa-inna l-nāsa la-yattabi'ūna-hū yasma'ūna șawta-hū wa-māyarawna-hū

Until a man of the ğinn approached from the lower part of Mecca, singing verses according to the Arab form of singing; and lo people were following him, listening to his voice though not able to see him. (Sira 1, 330)

Besides a close description of the situation, the wa-inna la- circumstantial conveys an evaluation of its remarkable nature (i.e., the enchanted people were following the man though not able to see him), an evaluation which brings to the fore the presence of an evaluating person.

\subsubsection{Eventive and Descriptive Background}

As already discussed above (10.2.1), the events in the narrative chain are discrete, particular, and sequential. The background is not characterized by any of these properties. Nevertheless, besides pure non-eventive descriptions, the

30 The 'implied author' is further back in the consciousness of the reader than the narrator. It is 'the mental picture of the author that a reader constructs on the basis of the text in its entirety', see Toolan, Narrative, $64 \mathrm{ff}$. 
background does contain events. Background events are distinct from mainline events by being non-sequential: they do not move narrative time forward, but recall an event from the perspective of the main-line zero vantage point. Descriptions, as opposed to both foreground and background events, contain static, continuous, or recurrent situations, which characterize a certain figure or state in the story. They are not time-determined but rather define a certain stretch of time, a state, an epoch, in which certain individuals operate. ${ }^{31}$

In Classical Arabic, the distinction between eventive and descriptive background is marked by both the verbal forms and the clausal type in which they are realized. Generally speaking, the compounds kāna fa'ala and kāna qad fáala serve to indicate background events, whereas kāna yaf'alu and kāna fāilan/maf'ūlan, alongside other nominal and adverbial kāna-compounds, constitute the descriptive background. The next pair of examples illustrates the transition from background units to the main-line and vice versa. In [10.23], the introductory background features the compound form kāna qad ba'ata; the event which is referred to precedes the plot in its entirety. In [10.24], a background unit is inserted within the narrative stream of events, in order to describe the character of Waraqa Ibn Nawfal; it features both eventive and noneventive forms:

(10.23) wa-kāna mūsā bnu 'imrāna qad ba'ața l-ğunūda 'ilā l-ğabābirati min 'ahli l-qurāyaġzū-hum fa-ba'ața mūsā bnu 'imrāna 'ilā l-'amālīqi ğayšan min banī 'isrǟìla wa-'amara-hum 'an yaqtulū-hum ğamīan

Mūsā b. 'Imrān had sent the troops to the tyrants from the people of the villages to attack them, then Mūsā b. Imrān sent an army of the Israelites to the Amalekites and commanded them to kill them all. (Riwāyāt 2, 7)

(10.24) hattā 'atat bi-hì waraqata bna nawfali [...] wa-kāna mrảan tanașsara fì l-ḡāhiliyyati wa-kāna yaktubu l-kitāba l-ibrāniyya fa-yaktubu mina l-inğli bi-l-ibraniyyati mā šăa llāhu 'an yaktuba wa-kāna šayhan kabìran qad 'amiya fa-qūlat la-hū hadïğatu

Until [Hadiğa] went with him to her cousin Waraqa b. Nawfal [...] and he was a man [who] became Christian in the $\breve{G}$ ähiliyya; he used to write

31 Ducrot, L'imparfait, 6, has expressed the same thought with respect to the imparfait in French: Lorsqu'un énoncé est à l'imparfait, son thème est nécessairement temporel [...] l'état ou l'événement constituant son propos sont présentés comme des propriétés, comme des caractéristiques du thème. 
in the Hebrew script and would write in Hebrew whatever God wished him to write from the Gospel. He was an old man who already lost his eyesight. Huadīğa then told him ... (S. Sặḥ, 5)

Not only kāna-clauses, but also circumstantial clauses can interrupt the plot in order to comment on some situation or entity mentioned in it. Circumstantial clauses comprising the form yaf'alu or the participle always exhibit the order of the nominal clause. They are descriptive in nature, referring to an ongoing situation or a state in which a certain person is found. In contrast, circumstantial clauses in which qad fa'ala occurs show, in the main, the order of the verbal clause. Although qad fáala embodies both a dynamic and a static aspect, its function in the narrative is eventive rather than purely descriptive, and therefore qad fa' a la circumstantials realize the order of event-oriented clauses (see above 4.5). The same as kāna qadfa'ala, wa-qad fáala recalls a previous event for the sake of orientation or amplification of the plot; unlike kāna qad fa'ala, the circumstantial wa-qad fa'ala is a dependent clause and thus can only take a subsequent position in the narrative sequence. The next example presents a series of background units. It starts with an introductory kāna fāilan compound followed by two circumstantial clauses, the first is topicalized and descriptive, comprising the form yaf'alu, the second is verb-initiated and eventive, comprising the form qad facala:

(10.25) kuntu 'āhidan bi-yadi rasūli llāhi wa-naḥnu natamāšăă ğamīan naḥwa l-mağribi wa-qad țafalat-i l-šamsu

I was holding the Messenger of God by the hand and we were walking together at sunset time while the sun was already near setting. (Tarih 1,61 )

Table 10.3 summarizes the discussion on free and dependent, eventive and descriptive background clauses in the narrative:

TABLE 10.3 Background clauses in the narrative

Verbal form / clause Dependency Type of background

\begin{tabular}{lll} 
kāna yaf'alu/fāilan & free (initial or subsequent) & descriptive \\
kāna qadfa'ala & free (initial or subsequent) & eventive \\
wa-huwayaf'alu/fä'ilun & dependent & descriptive \\
wa-qadfáala & dependent & eventive \\
\hline
\end{tabular}




\subsection{Setting-presentative Constructions}

The syntactic structure of setting and presentative clauses which involve the predicative paradigm was discussed earlier (8.4). In this section, I would like to make some observations regarding the textual functions of these types of clauses.

Setting and presentative clauses are not found in any type of discourse, but only in narratives. They are therefore different from other structures of orientation and perception, such as circumstantial and complement clauses, which are not text-specific. The following pairs of examples illustrate the distinction between complement and presentative clauses ([10.26]-[10.27]), and between circumstantial and setting clauses $([10.28]-[10.29])$ :

(10.26) lammā ra’aytu bna 'ubayyin ğālisan fin nạhiyati l-bayti

When I saw Ibn 'Ubayy sitting at the corner of the house ... (Majīazi 370)

(10.27) dahaltu l-masğida fa-'id̄à rasūlu llāhi ğālisun waḥda-hū

I entered the mosque and there the Messenger of God was sitting all by himself. (Ta'ihh 1, 152)

(10.28) fa-ǧăàa 'ilà rasūli llāhi wa-huwa ğālisun fíaṣhābi-hī

He came to the Messenger of God while he was sitting with his companions. (Mag்āzī, 370)

(10.29) baynamā huwa ğālisun fi l-masǧidi wa-l-nāsu ma'a-hū ’id 'aqbala talàtatu nafarin

While he was sitting in the mosque and the people were [sitting] with him, suddenly three men approached. (Șahịh, 28)

Complement clauses of perception verbs and presentative clauses both convey a perceived situation. They may refer to the same state of affairs in the world. The difference between them resides in what may be described as the expressive mode in which this state of affairs is represented. A complement clause is a diegetic device: it relates the facts from the neutral (unmarked or 'zero') vantage-point of the speaker/narrator. A presentative clause, by contrast, is a mimetic device: it transmits the situation from the internal point of view of the perceiver (be it the narrator or a character in the narrative). The contrast between complement and presentative clauses comes into play in the narrative: in the first case, the narrator tells the story in a plain neutral manner; in 
the latter case, the events are presented as enacted or experienced, thus the narrative is given a dramatic impact. ${ }^{32}$

In a similar manner, the contrast between plain and dramatic representation appears to determine the choice between circumstantial and setting clauses in the narrative. Both types of clauses, the preposed setting and the postposed circumstantial, provide the frame in which the main event takes place. However, as observed by several linguists, preposed adverbial clauses, being associated with both the preceding and the following text, have a broader scope of reference than those postposed. ${ }^{33}$ This makes them suitable to serve a special function in the narrative, namely, to relate the previous episode to the succeeding one and to indicate the background from which a dramatic development emerges.

Setting and presentative clauses contribute to the creation of the narrative identity or narrativity of the text. Not only do they shape the narrative structure, serving as either grounding or 'relief' devices, but also at the metalinguistic level, setting and presentative clauses are indices of narrativity: their presence in the text marks the message itself as narrative. ${ }^{34}$

\subsubsection{Setting and Preposed Temporal Clauses}

As far as their function in the narrative is concerned, setting clauses introduced by baynā/baynamā can be paired-off with preposed temporal clauses introduced by lammā (see also above 7.4). Both types of clauses share some structural similarities: they take the first position in the complex construction (like conditional clauses) and are followed by fa'ala in the second clause; both lammā and baynā/baynamā can be preceded by the conjunction fa-. However, in lammā-clauses the verbal form fa'ala comes right after the operator,

32 The distinction between the plain and the dramatic mode of expression should not be equated with the distinction between an objective and a subjective mode of description. Expressivity, as a reflection of subjectivity in language, is a scalar phenomenon. Lyons, Deixis and Subjectivity, 107-108, for instance, views the distinction between propositional and non-propositional complement clauses (e.g. 'I remember switching off the light' vs. 'I remember that I switched off the light') as having to do with the subjective, in the first case, or objective, in the latter case, mode in which the situation is described. Thus, a plain expressive mode can be more or less subjective; a dramatic mode of expression is by definition subjective.

33 Cf. Chafe, Adverbial Clauses and Ramsay, Functional Distribution.

34 Fleischman, Tense and Narrativity, 78, defines the 'metalinguistic' component of the linguistic system as 'a language's resources for talking about itself'; it includes such functions as the signaling of 'a particular style, register, genre, or type of discourse'. 
while baynā/baynamā-clauses exhibit the order of the nominal clause, where the subject precedes the verbal predicate yaf'alu or the participle. Table 10.4 summarizes the structural properties of lamm $\bar{a}$-clauses and baynā/baynam $\bar{a}-$ clauses:

TABLE 10.4 lammā: baynā/baynamā

\begin{tabular}{|c|c|c|}
\hline Pattern & $\mathbf{A}$ & B \\
\hline preposed temporal clause & (fa-)lammā fáala & fáala \\
\hline setting clause & $(f a-)$ bayna $(m \bar{a}) \mathrm{N}^{\text {nom }}$ yaf'alu/ fāilun & $\left(f a-/{ }^{\prime} i d\right)$ fa'ala \\
\hline
\end{tabular}

Not only in their structure but also in their function, preposed temporal clauses and setting clauses are similar: both convey a backgrounded or expository piece of information that anticipates a dramatic development in the plot. The difference is that lammā-clauses introduce anterior events while baynā/baynam $\bar{a}$ clauses introduce ongoing situations with yaf'alu or states with the participle. Moreover, lammā-clauses are mostly anaphoric, presenting information that is accessible from the previous context. baynā/baynama $\bar{a}$-clauses, on the other hand, are primarily cataphoric, often initiating a new episode of the narrative. ${ }^{35}$ The following examples illustrate the function of these two types of clauses:

(10.30) fa-lammā sāra ġayra baìdin-i 'tarada la-hū dỉbun

After he went not too far, [suddenly] a wolf stood in his way. (Kalìla wa-Dimna, 63)

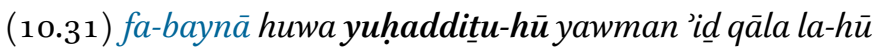

While he was talking to him one day, he suddenly said to him. (Riwāyāt 1, 59)

(10.32) baynā 'anā nā̉imun 'utītu bi-qadahi labanin

While I was sleeping, I was [suddenly] brought a cup of milk. (Șahịh, 33)

35 On the distinction between anaphoric and cataphoric grounding, see Givón, Beyond Foreground, $180-181$. 
Example [10.30] follows right after the opening clause of the story, 'inna rağulan salaka mafāzatan 'a man travelled the desert'. The event of 'going' reported in the lammā-clause belongs to the same referrential domain as the 'travelling', and is in fact a specification thereof. By contrast, [10.31]-[10.32] open new episodes in the narrative; they depict the background in which a dramatic happening emerges.

Setting clauses can also take the form of the 'inna la-pattern. As noted earlier (8.4.1), the distinction between this pattern and the regular baynāalbaynamā pattern lies in the domain of expressivity. The 'inna la-pattern allows the first person narrator-who marks an external point of reference-to signal his internal involvement as a character in the narrative:

(10.33) 'innā la-nataraḥhalu 'ilà 'arḍi l-ḥabašati [...] 'id 'aqbala 'umaru bnu lhatțābi

We were departing to Abyssinia [...] when suddenly 'Umar b. al-Huațāa approached. (Sïra, 225)

\subsubsection{Presentative Clauses}

Presentative clauses take the second position in the complex construction. They can be classified into two kinds: dynamic and static. Dynamic presentatives are often introduced by the particle ' $i d$ followed by the verbal form fa'ala. The structure of static presentatives, which are introduces by the particle 'id $\bar{a}$, was presented above (8.4.2). Both 'i $\underline{d}$ and 'id $\underline{\text { a }}$ can be preceded by the conjunction $f a$ - (and occasionally by $w a$-). Table 10.5 summarizes the structural properties of presentatives introduced by 'id and 'id $\underline{i}$ :

TABLE 10.5 'id : 'idāā

Pattern A

B

dynamic (fa-)bayna $(m \bar{a}) \mathrm{N}^{\text {nom }}$ yaf'alu/făcilun $\left(f a-/{ }^{\prime} i d\right)$ fa'ala

presentative

static fáala

fa-/wa-'idā Nom yaf'alu/fā'ilun/qad fáala

presentative

Presentative clauses introduced by 'id and 'id̄a express something unexpected, mufāğa'a 'surprise' in traditional terms, a sudden development or realization, perceived or grasped by a certain character. However, while 'id-clauses present 
a further progression in the plot, 'id $\underline{a}$-clauses present an unfolding scene, a tableau, hence the above distinction between dynamic and static presentatives. In both cases the overall construction exhibits what may be described as an aspectual asymmetry. In 'id-initiated presentatives, a static situation (baynā /baynamā-clause) is interrupted by a dynamic peak in the story. In 'id $\bar{a}-$ initiated presentatives, a dynamic step forward in the plot ( fa'ala) is concluded in a static situation. It is this aspectual asymmetry that creates the dramatic moment of surprise in the narrative. The examples below illustrate the distinction between the two types of presentative constructions. In [10.34] the presentative is introduced by 'i $\underline{d}$ while in [10.35]-[10.37], reproducing [8.110][8.112], the presentative is introduced by 'i $\underline{d} \bar{a}$ followed by the predicative forms:

\section{(10.34) baynā 'anā 'amšš 'id samitu șawtan min-a l-samā’i}

While I was walking, all of a sudden I heard a voice from the sky. (Șahịh, 6)

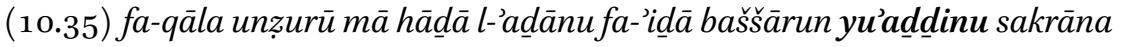
And he said: 'Look what is this call!' And there was Baššār calling for prayer while drunk. (Riwāàāt 1, 261)

(10.36) fa-ğìtu 'ilā 'ibrāhìma l-mawșiliyyi fa-ìdà l-bābu maftūḥun wa-l-dihlīzu qad kunisa wa-l-bawwābu qāंidun

I came to 'Ibrāhìm al-Mawșilī, and behold, the door was opened, the hall was already swept, and the door-keeper was sitting. (Riwāyāt 1, 28)

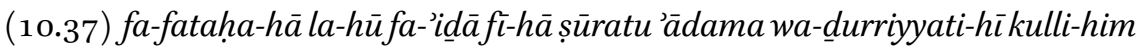
fa-'idà kullu rağulin maktūbun 'inda-hü 'ağalu-hū wa-'id̄a 'àdamu qad kutiba la-hü 'umru'alfi sanatin (Ta'rīh 1, 156)

He opened it (i.e. His hand) for him, and behold, in it there was the picture of Adam and all his progeny, and there was the [life] term of each man written down with Him, and there was Adam, a term of thousand years already written down for him.

\subsection{Generic Narratives}

The hitherto discussion of Classical Arabic narrative structure accounts for the great majority of narratives found in the corpus. Nearly all the narratives consist of a fa'ala-initiated chain of events, which is amplified by background units; some also feature dramatic patterns, such as the setting-presentative 
constructions. Nevertheless, one can occasionally encounter other forms of narration. The following anecdote, extracted from Kitāb al-Buhală' 'The Book of Misers', is a case in point:

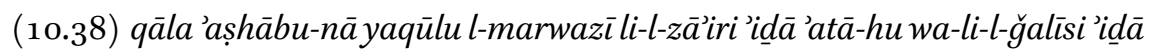
țāla ğulūsu-hū taġaddayta l-yawma fa-'in qāla na'am qāla lawlà 'anna-

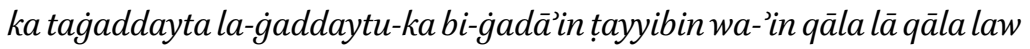

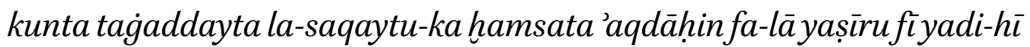
'alā l-wağhayni qalìlun wa-là katìirun

Our friends say: "The Marwazī says to a visitor when he comes to his [house] and to a companion when he extends his stay [with him]: "Have you had your midday meal today?" If he answers "Yes" he says: "If you hadn't already had your midday meal I would have given you a fine midday meal," and if he says "No" he says: "If you had had your midday meal I would have poured you five bowls of a drink." So neither a little nor a lot would come into his hand.' (Buhalä, 37)

The quoted passage seems to fit well Koch's definition of an anecdote:'a shortoriginally orally transmitted—narrative told about a well-known person, either a nationally prominent figure or a local character, to highlight his character or that of a social group or epoch this person represents.' ${ }^{36} \mathrm{Al}-$ Ğāhiz tells the story about the Marwazi in order to demonstrate the miserliness of the people of Khurasan. The story has in it a comic element, which is also inherent to the anecdotal style.

As far as its syntactic structure is concerned, this anecdote presents a great deviation from the narrative structure discussed above. For one thing, the story does not consist of a fa'ala-initiated chain and digression to background units therefrom. For another, the reference point of the story is neither internalthe narrative is not detached and self-contained-nor is it external, referring to the present situation of a particular narrator. Instead, the narrative consists of a sequence of generic verbal clauses: simple clauses comprising the verbal form yaf'alu, and conditional constructions comprising the verbal form fa'ala. Indeed, this narrative is essentially different from an ordinary narrative in being generic: though it does tell us of a sequence of events, these events are not discrete and particular, they did not happen to a certain person at a certain time and place, but would happen to a certain type of person whenever a certain type of situation arises. Generic narratives, according to Fleischman, 'relate

$36 \quad$ Koch, Simple Forms, 7 . 
what used to be the case in the past or what normally occurs in the present'. ${ }^{37}$ I apply this term to anecdotes such as the one quoted, since these set foot in both the domains of the narrative and the generic utterance: on the one hand, they report on a sequence of events in order to make a certain point, thus they have both the cohesive structure of a narrative and its pragmatic motivation; on the other hand, they are not anchored in a particular situation but refer to an always valid state of affairs.

\subsection{Summary}

In this chapter, I have discussed the main types of clauses which are found in Classical Arabic narratives and the way in which they contribute to the shaping of the narrative's overall structure. I have pointed out the major role of fa'ala as the eventive chain-initiating form, and distinguished between three types of chains: (a) the externally reported sequence of events marked by the facala conN-fáala pattern, (b) the internally portrayed complex event marked by the fa'ala yaf'alu/ fácilan pattern, and (c) the consequentially related events indicated by the fa'ala fa-yaf'alu pattern. Further, I have discussed background patterns in the narrative and distinguished between introductory (free) and subsequent (free or dependent) units, and between eventive and descriptive amplifications of the narrative. I have also made some observations regarding dramatic devices such as setting and presentative clauses. It was shown that the preference of a certain narrating strategy is not due to (macro-)syntactic constraints, but follows from the external or internal, involved (subjective and expressive) or uninvolved (objective and plain) position assumed by the narrator.

37 Fleischman, Tense and Narrativity, 104. 